\title{
Studi Komperatif Hak dan Kewajiban Konsumen Menurut UU No. 8 Tahun 1999 Tentang Perlindungan Konsumen dan Hukum Islam
}

\author{
Nurul Tika Pratiwi dan Aprina Chintya
}

Institusi Agama Islam Negeri Metro

E-mail: aprinachintya64gmail.com,

\begin{abstract}
Manufacturers strive to make efforts to attract consumers. Unfortunately, efforts to do that sometimes lead to negative things, even from the beginning starting with bad faith, such as by providing false information, misleading information, the quality or the quality of goods is low, even in ways sales are imposing. This makes the consumer as the weak and vulnerable to injustice and deception from the manufacturer. Therefore, this study aims to look at the comparison of consumer protection, according to Law No. 8 of 1999 on Consumer Protection and the Law of Islam. This research is a qualitative descriptive literature. Collecting data in this study through the documentation. Meanwhile, data analysis technique used is content analysis. The results showed that the existence of Act No. 8 of 1999 on Consumer Protection and the Law of Islam joined efforts to provide protection to the consumer. From some of the similarities and differences between the Law No. 8 of 1999 on Consumer Protection and the Law of Islam, suggesting that Islamic law is more comprehensive and flexible in providing protection to the consumer.
\end{abstract}

Keywords: Consumer, Legal Protection, Producers, Rights, Islamic Law.

Abstrak
Produsen terus melakukan berbagai upaya untuk menarik hati konsumen. Sayangnya, upaya-upaya yang dilakukan tersebut kadangkala menjurus pada hal yang negatif, bahkan dari sejak awal dimulai dengan itikad tidak baik, antara lain dengan memberikan informasi yang tidak 
benar, informasi yang menyesatkan, mutu atau kualitas barang yang rendah, bahkan dengan cara-cara penjualan yang bersifat memaksakan. Hal ini membuat konsumen sebagai pihak yang lemah dan rentan terhadap ketidakadilan dan kecurangan dari produsen. Oleh sebab itu, penelitian ini bertujuan melihat perbandingan perlindungan konsumen menurut UU No. 8 Tahun 1999 tentang Perlindungan Konsumen dan Hukum Islam. Penelitian ini adalah penelitian pustaka yang bersifat deskriptif kualitatif. Pengumpulan data dalam penelitian ini melalui dokumentasi. Sedangkan, teknik analisis data yang digunakan adalah konten analisis. Hasil penelitian menujukkan bahwa keberadaan Undang-Undang Nomor 8 Tahun 1999 tentang Perlindungan Konsumen dan Hukum Islam sama-sama berupaya untuk memberikan perlindungan terhadap konsumen. Dari beberapa persamaan dan perbedaan antara Undang-Undang Nomor 8 Tahun 1999 tentang Perlindungan Konsumen dan Hukum Islam, menunjukkan bahwa hukum Islam lebih luas dan fleksibel dalam memberikan perlindungan terhadap konsumen.

Kata Kunci: Konsumen, Perlindungan Hukum, Produsen, Hak, Hukum Islam.

\section{A. Pendahuluan}

\section{Latar Belakang}

Konsumen yang keberadaannya sangat tidak terbatas, dengan strata yang sangat bervariasi menyebabkan produsen melakukan kegiatan pemasaran dan distribusi produk barang atau jasa dengan cara-cara yang seefektif mungkin agar dapat mencapai konsumen yang sangat majemuk tersebut. Oleh karena itu berbagai upaya dilakukan untuk mencapai sasaran tersebut di atas. ${ }^{1}$

Upaya-upaya yang dilakukan tersebut kadangkala menjurus pada hal yang negatif, bahkan dari sejak awal

1 Sri Redjeki Hartono, Aspek-aspek Hukum Perlindungan Konsumen Dalam Menghadapi Era Perdagangan Bebas, (Bandung: UNISBA, 1998), hlm. 2. 
dimulai dengan itikad tidak baik, antara lain dengan memberikan informasi yang tidak benar, informasi yang menyesatkan, mutu atau kualitas barang yang rendah, bahkan dengan cara-cara penjualan yang bersifat memaksakan. Hal ini membuat konsumen sebagai pihak yang lemah dan rentan terhadap ketidakadilan dan kecurangan dari produsen.

Dewasa ini, sebetulnya telah tumbuh kesadaran masyarakat tentang perlunya perlindungan konsumen yang dimulai dinegara-negara maju. Apabila dimasa lalu pihak industriawan yang dipandang sangat berjasa bagi perkembangan perekonomian negara sehingga mendapat perhatian sangat besar, maka dewasa ini perlindungan terhadap konsumen lebih mendapat perhatian sesuai dengan semakin meningkatnya perlindungan terhadap Hak Asasi Manusia. $^{2}$

Perlindungan terhadap konsumen berkaitan dengan kegiatan bisnis, yaitu perdagangan barang dan jasa dalam lingkup kegiatan ekonomi. Namun demikian tidak dapat dilepaskan dari aspek-aspek lain seperti hukum, agama, pendidikan, sosial dan budaya.

Salah satu hal yang perlu dicermati adalah masalah perlindungan konsumen dalam hukum Islam. Hal ini penting karena penduduk Indonesia mayoritas beragama Islam, dengan demikian semestinya nilai-nilai ajaran Islam melandasi peraturan perundang-undangan yang mengatur kegiatan perekonomian masyarakat dalam berbagai bidang. ${ }^{3}$

Islam merupakan agama yang komprehensif dan universal. Dikatakan komprehensif, karena Islam mengatur seluruh aspek kehidupan manusia. Universal karena daya berlakunya tidak terbatas oleh waktu dan tempat. Masalah bisnis, perdagangan/ perniagaan/ perekonomian merupakan

\footnotetext{
${ }^{2}$ Ibid.

${ }^{3}$ Neni Sri Imaniyati, Hukum Ekonomi dan Ekonomi Islam Dalam Perkembangan, (Bandung: Mandar Maju, 2002), hlm. 162.
} 
salah satu bidang muamalah, Islam telah menyediakan rambu-rambunya.

Dalam bidang ibadah, Islam menetapkan hukum "tidak ada ibadah kecuali yang diatur dalam Al Qur'an dan Sunnah". Oleh karena itu ibadah yang dilakukan di luar Al Qur'an dan Sunnah termasuk bid'ah, sedangkan untuk kegiatan muamalah Islam hanya mengatur prinsip-prinsipnya saja.

Berbicara tentang etika bisnis, maka harus merujuk ke prinsip-prinsip ekonomi Islam, yaitu:

a. Islam menentukan berbagai kerja yang halal dan haram. Kerja yang halal saja yang dianggap sah;

b. Kerjasama yang bersifat gotong royong dalam usaha memenuhi kebutuhan harus ditegakkan;

c. Nilai keadilan dalam kerjasama ditegakkan. ${ }^{4}$

Secara khusus Islam menetapkan nilai-nilai atau etika yang harus dipatuhi dalam kegiatan bisnis yang merupakan tolok ukur kejujuran, kepercayaan dan ketulusan, seperti larangan sumpah palsu, larangan memberikan takaran yang tidak benar dan keharusan beritikad baik dalam transaksi bisnis.

Masyarakat muslim tidak bebas tanpa kendali dalam memproduksi segala sumber daya alam, mendistribusikannya atau mengkonsumsikannya. Ia terikat dengan buhul akidah dan etika mulia, disamping juga dengan hukum-hukum Islam. Berdasarkan hal inilah, yang mendorong penulis melakukan penelitian dengan judul "Studi Komperatif Perlindungan Konsumen Menurut UU No. 8 Tahun 1999 tentang Perlindungan Konsumen dan Hukum Islam ”

4 Achmad Aghar Basyir, Prinsip-prinsip Ekonomi Islam Dalam Bebagai Aspek Ekonomi Islam, (Yogyakarta: P3Ei-FE UII bekerjasama dengan Penerbit Tiara Wacana, 1992), hlm. 13-14 


\section{Rumusan Masalah}

Mengacu pada latar belakang masalah di atas, masalah dalam penelitian ini dirumuskan sebagai berikut: Bagaimana perbandingan perlindungan konsumen menurut UU No. 8 Tahun 1999 tentang Perlindungan Konsumen dan Hukum Islam?

\section{B. Perlindungan Hukum Konsumen}

Menurut Janus Sidabalok, perlindungan hukum adalah memberikan pengayoman terhadap hak asasi manusia yang dirugikan orang lain dan perlindungan tersebut diberikan kepada masyarakat, agar dapat mereka nikmati semua hakhak yang diberikan oleh hukum. ${ }^{5}$

Perlindungan hukum menurut Adnan Buyung Nasution sebagaimana dikutip Celina Tri Siwi Kristiyanti, adalah melindungi harkat dan martabat manusia dan melindungi sesuatu dari 8 Mukadimah Konsep Penyempurnaan Anggaran Dasar, Peraturan Rumah Tangga, Kode Etik Advokad, Hukum Acara Dewan Kehormatan, untuk disahkan Kongres ke-6 Peradilan di Bandung, 4 - 6 Juni 1981, Panitia Penyelenggara Peradilan pemerkosaan, yang dasarnya serangan hak kepada orang lain telah melanggar dari aturan norma hukum dan undang-undang. ${ }^{6}$

Para ahli hukum pada umumnya sepakat bahwa arti konsumen adalah pemakai terakhir dari benda dan jasa (vitendelijke gebruiker van goerderen endiesten) yang diserahkan kepada mereka oleh pengusaha (ondernamer). ${ }^{7}$

Dalam buku Az. Nasution yang berjudul Aspek-aspek Hukum Masalah Perlindungan Konsumen, istilah konsumen

5 Janus Sidabalok, Hukum perlindungan Konsumen, (Bandung: PT. Citra Aditya Bakti, 2006), hlm. 3

${ }^{6}$ Celina Tri Siwi Kristiyanti, Hukum Perlindungan Konsumen, (Jakarta: Sinar Grafika, 2009), hlm. 22

7 Badan Pembinaan Hukum Nasional (BPHN) Departemen Kehakiman, Simposium, Aspek-Aspek Hukum Masalah Perlindungan Konsumen, (Jakarta: Binacipta, 1986), hlm. 43 
berasal dari alih bahasa dari kata consumer (InggrisAmerika), atau consument (Belanda). Secara harfiah arti kata dari consumer itu adalah "(lawan dari produsen) setiap orang yang menggunakan barang”. Tujuan penggunaan barang atau jasa itu nanti menentukan termasuk konsumen kelompok mana pengguna tersebut. ${ }^{8}$

Begitu pula Kamus Bahasa Inggris-Indonesia memberi arti kata consumer sebagai "pemakai atau konsumen". 9 Az. Nasution juga mengemukakan beberapa batasan tentang konsumen, yaitu :

a. Konsumen adalah setiap orang yang mendapatkan barang atau jasa digunakan untuk tujuan tertentu.

b. Konsumen antara adalah setiap orang yang mendapatkan barang dan/atau jasa untuk digunakan dengan tujuan membuat barang atau jasa lain untuk diperdagangkan (tujuan komersial).

c. Konsumen akhir adalah setiap orang alami yang mendapatkan dan menggunakan barang dan/atau jasa untuk tujuan memenuhi kebutuhan hidupnya pribadi, keluarga, dan atau rumah tangga dan tidak untuk diperdagangkan kembali (non komersial). ${ }^{10}$

Di dalam Undang-Undang Nomor 5 Tahun 1999 tentang Larangan Praktek Monopoli dan Persaingan Usaha Tidak Sehat memuat suatu definisi tentang konsumen, yaitu "setiap pemakai dan atau pengguna barang dan atau jasa, baik untuk kepentingan sendiri maupun untuk kepentingan orang lain." 11

Sedangkan berdasarkan Pasal 1 Angka (2) UndangUndang No.8 Tahun 1999 tentang Perlindungan Konsumen

${ }^{8}$ Az. Nasution, Hukum Perlindungan Konsumen-Suatu Pengantar, (Jakarta: Daya Widya, 1999), hlm. 3.

${ }^{9}$ Ibid.

${ }^{10}$ Ibid, hlm. 13-14

11 Shidarta, Hukum Perjanjian Konsumen Indonesia, (Jakarta: Grasindo, 2000), hlm. 2 
(UUPK) yang dimaksud dengan pengertian konsumen yaitu "setiap orang pemakai barang dan/atau jasa yang tersedia dalam masyarakat, baik bagi kepentingan diri sendiri, keluarga, orang lain, maupun makhluk hidup lain dan tidak untuk diperdagangkan.”

Menurut Penjelasan Pasal 1 Angka (2) UUPK disebutkan bahwa di dalam kepustakaan ekonomi dikenal istilah konsumen akhir dan konsumen antara. Konsumen akhir adalah pengguna atau pemanfaat akhir dari suatu produk, sedangkan konsumen antara adalah konsumen yang menggunakan suatu produk sebagai bagian dari proses produksi suatu produk lainnyaPengertian konsumen dalam undang-undang ini adalah konsumen akhir.

Ada yang berpendapat, hukum perlindungan konsumen merupakan bagian dari hukum konsumen yang lebih luas. Az. Nasution, misalnya berpendapat bahwa : "Hukum perlindungan konsumen merupakan bagian dari hukum konsumen yang memuat asas-asas atau kaidah-kaidah bersifat mengatur, dan juga mengandung sifat yang melindungi kepentingan Konsumen ." 12

Selain berpendapat seperti itu, Az. Nasution juga mengemukakan bahwa: Hukum perlindungan konsumen merupakan bagian dari hukum konsumen yang memuat asasasas atau kaidah-kaidah bersifat mengatur dan juga mengandung sifat yang melindungi kepentingan konsumen. Hukum konsumen adalah hukum yang bersifat komperhensif mencakup berbagai hal. Sedangkan hukum perlindungan konsumen lebih merupakan bagian yang khusus mengatasi perlindungan Konsumen. ${ }^{13}$

Perlindungan hukum terhadap konsumen dapat dilakukan pada saat sebelum terjadinya transaksi (no conflict/pre purchase) dan/atau pada saat setelah terjadinya

\footnotetext{
${ }^{12}$ Ibid, hlm. 9

${ }^{13}$ Az. Nasution, Konsumen dan Hukum, hlm. 82
} 
transaksi (conflict/post purchase). ${ }^{14}$ Perlindungan hukum terhadap konsumen yang dilakukan pada saat sebelum terjadinya transaksi (no conflict/pre purchase) dapat dilakukan dengan cara :

a. Legislation, yaitu perlindungan hukum terhadap konsumen yang dilakukan pada saat sebelum terjadinya transaksi dengan memberikan perlindungan kepada konsumen melalui peraturan perundangan yang telah dibuat. Sehingga dengan adanya peraturan perundangan tersebut diharapkan konsumen memperoleh perlindungan hukum sebelum terjadinya transaksi, karena telah ada batasanbatasan dan ketentuan-ketentuan yang mengatur transaksi antara konsumen dan pelaku usaha.

b. Voluntary Self Regulation, yaitu perlindungan hukum terhadap konsumen yang dilakukan pada saat sebelum terjadinya transaksi, dimana dengan cara ini pelaku usaha diharapkan secara sukarela membuat peraturan bagi dirinya sendiri agar lebih hati-hati dan waspada dalam menjalankan usahanya. ${ }^{15}$

Kedua cara ini diharapkan dapat mencegah dan meminimalisir agar tidak terjadi konflik pada saat sebelum terjadinya transaksi antara konsumen dengan pelaku usaha. Hal ini dikarenakan banyak sekali terjadi masalah saat transaksi antara konsumen dengan pelaku usaha.

UUPK juga mengatur perlindungan hukum terhadap konsumen sebelum terjadinya transaksi. Di dalam Penjelasan Umum Angka 1 UUPK dijelaskan bahwa, undang-undang Perlindungan Konsumen dimaksudkan menjadi landasan hukum yang kuat bagi pemerintah dan lembaga perlindungan konsumen swadaya masyarakat untuk melakukan upaya pemberdayaan konsumen melalui pembinaan dan pendidikan Konsumen .

\footnotetext{
${ }^{14}$ Ibid

${ }^{15}$ Ibid, hlm. 4
} 
Pengertian perlindungan konsumen disebutkan dalam Pasal 1 Angka (1) UUPK, yaitu "Segala upaya yang menjamin adanya kepastian hukum untuk memberi perlindungan kepada konsumen." ${ }^{\text {"16 }}$ Oleh karena itu dalam Penjelasan Umum Angka 1 UUPK disebutkan bahwa, perlu upaya pemberdayaan konsumen melalui pembentukan undang-undang yang dapat melindungi kepentingan konsumen secara integratif dan komprehensif serta dapat diterapkan secara efektif di masyarakat. karena tidak udah mengharapkan kesadaran pelaku usaha, yang pada dasarnya prinsip ekonomi pelaku usaha adalah mendapat keuntungan yang semaksimal mungkin dengan modal seminimal mungkin.

Sedangkan untuk perlindungan hukum terhadap konsumen pada saat setelah terjadinya transaksi (conflict/post purchase) dapat dilakukan melalui jalur Pengadilan Negeri (PN) atau di luar Pengadilan oleh Badan Penyelesaian Sengketa konsumen (BPSK), berdasarkan pilihan para pihak yang bersengketa.

Dimensi sosial dari hukum dewasa ini kian hari kian tampak menonjol. Keterlibatan hukum pada persoalanpersoalan sosial dan ekonomi bangsa serta tuntutan agar hukum mampu berperan sebagai sarana untuk memecahkan berbagai problem sosial yang demikian itu menampilkan kisikisi yang lain dari hukum yang tidak hanya yuridis dogmatis. $^{17}$

Dilingkungan masyarakat telah tumbuh etika bisnis, khususnya berkaitan dengan perlindungan konsumen, yang pada pokoknya telah cukup memberikan perlindungan kepada konsumen dari tindakan-tindakan pelaku usaha.

16 Undang-undang No. 8 TAhun 1999 tentang Perlindungan Konsumen Pasal 1 Angka (1).

17 Satjipto Rahardjo, Pembangunan Hukum Yang Diarahkan Kepada Tujuan Nasional, (Yogyakarta: Tiara Wacana, 2009), hlm. 2 
Namun demikian etika saja masih dianggap kurang tanpa hukum. Etika, seperti halnya norma kesusilaan, norma kesopanan dan norma agama, sebelum diterima sebagai hukum, sanksi atas pelanggaran dari norma-norma tersebut lebih bersifat heteronom atau datang dari diri dan hatinya sendiri dalam bentuk penyesalan, rasa malu, rasa berdosa dan sebagainya. Oleh karena itu agar memiliki daya pengikat sehingga sanksi kepada para pelanggar dapat dipaksakan, maka diperlukan hukum (dalam hal ini adalah Undangundang). ${ }^{18}$

Lahirnya UU Perlindungan Konsumen, tidak dapat dipisahkan dari perjalanan panjang gerakan perlindungan konsumen di dunia. Dalam perjalanan gerakan perlindungan konsumen dikenal dua macam adagium, yaitu caveat emptor (waspadalah konsumen) yang kemudian menjadi caveat venditor (waspadalah produsen). Kedua caveat ini erat kaitannya dengan strategi bisnis pelaku usaha. Tahun 1999 telah disahkan Undang-Undang Nomor 8 Tahun 1999 tentang Perlindungan Konsumen.

Walaupun undang-undang tersebut berjudul UU Perlindungan Konsumen, namun ketentuan di dalamnya lebih banyak mengatur tentang perilaku pelaku usaha. Hal ini dapat dipahami. Karena kerugian yang diderita oleh konsumen sering kali akibat dari pelaku usaha, sehingga perilaku pelaku usaha ini perlu diatur dan bagi para pelanggar dikenakan sanksi yang setimpal.

Esensi dari undang-undang Nomor 8 Tahun 1999 tentang Perlindungan Konsumen adalah mengatur perilaku pelaku usaha dengan tujuan agar konsumen terlindungi secara hukum. Dalam undang-undang ini menetapkan lima materi pokok yaitu :

${ }^{18}$ Moh. Mahfud MD, Pewadahan Etika Keilmuan di Dalam UU Hak Cipta, Jurnal Hukum Ius Quiaiustum UII, (Yogyakarta, 1999), hlm. 36 
a. Larangan-larangan yang berkaitan dengan produk dan pelaku usaha;

b. Tanggung jawab produsen dan tanggung gugat produk;

c. Perjanjian atau klausula baku;

d. Penyelesaian sengketa dan

e. Ketentuan pidana.

Dengan mengkaji pasal demi pasal dalam UU Perlindungan Konsumen, tampak bahwa beberapa ketentuan yang tertera dalam undang-undang tersebut sesuai dengan nilai-nilai etika bisnis Islam, walaupun dengan redaksi yang berbeda akan tetapi substansi dan tujuannya adalah sama, yaitu untuk melindungi konsumen. Hal ini dapat dilihat dari aturan-aturan mengenai keharusan beritikad baik dalam melakukan usaha (Psal 7 huruf a), jujur (Pasal 7 huruf b), jujur dalam takaran atau timbangan (Pasal 8 ayat (1) huruf a, b, c, d, e), menjual barang yang baik mutunya (Pasal 8 ayat $(2,3,4))$, larangan menyembunyikan barang yang cacat (Pasal 8).

Namun, adabeberapa hal hukum Islam tidak ter "cover" dalam UU Perlindungan Konsumen, seperti larangan memperjualbelikan barang/jasa yang haram, larangan riba dan keharusan zakat. Untuk itu, perlu dukungan dari masyarakat mayoritas Islam untuk mendesak pemerintah agar membuat aturan yang mengandung syariat Islam. Selain itu, perlu dipikirkan bagaimana upaya penegakan hukum, yaitu peraturan yang telah sesuai dengan aturan dalam Hukum Islam.

\section{Perlindungan Konsumen dalam UU No. 8 Tahun 1999 Tentang Perlindungan Konsumen dan Hukum Islam}

Perlindungan konsumen adalah segala upaya yang menjamin adanya kepastian hukum untuk memberikan 
perlindungan kepada konsumen ${ }^{19}$ Upaya menjaga harkat dan martabat konsumen perlu didukung peningkatan kesadaran, pengetahuan, kepedulian, kemampuan, dan kemandirian konsumen untuk melindungi dirinya serta menumbuhkembangkan sikap pelaku usaha yang bertanggung jawab. ${ }^{20}$

Menurut Undang-Undang Perlindungan Konsumen Nomor 8 Tahun 1999 Tentang Perlindungan Konsumen Republik Indonesia menjelaskan bahwa hak konsumen di antaranya adalah hak atas kenyamanan, keamanan, dan keselamatan dalam mengkonsumsi barang dan atau jasa. Hak untuk memilih barang dan atau jasa serta mendapatkan barang dan atau jasa tersebut sesuai dengan nilai tukar dan kondisi serta jaminan yang dijanjikan; hak untuk diperlakukan atau dilayani secara benar dan jujur serta tidak diskriminatif; hak untuk mendapatkan kompensasi, ganti rugi dan atau penggantian, apabila barang dan atau jasa yang diterima tidak sesuai dengan perjanjian atau tidak sebagaimana mestinya; dan sebagainya.

Sesuai dengan Pasal 4 Undang-undang Perlindungan Konsumen (UUPK), Hak-hak Konsumen adalah :

1. Hak atas kenyamanan, keamanan dan keselamatan dalam mengkonsumsi barang dan/atau jasa;

2. Hak untuk memilih barang dan/atau jasa serta mendapatkan barang dan/atau jasa tersebut sesuai dengan nilai tukar dan kondisi serta jaminan yang dijanjikan;

3. Hak atas informasi yang benar, jelas dan jujur mengenai kondisi dan jaminan barang dan/atau jasa;

4. Hak untuk didengar pendapat dan keluhannya atas barang dan/atau jasa yang digunakan;

${ }^{19}$ Siahaan, Hukum Perlindungan Konsumen dan Tanggung Jawab Produk, (Jakarta: Panta Rei, 2005), hlm. 100.

20 Ahmadi dan Yodo, Hukum Perlindungan Konsumen, (Jakarta : Rajawali Pers, 2004), hlm. 57. 
5. Hak untuk mendapatkan advokasi, perlindungan dan upaya penyelesaian sengketa perlindungan konsumen secara patut;

6. Hak untuk mendapat pembinaan dan pendidikan konsumen;

7. Hak untuk diperlakukan atau dilayani secara benar dan jujur serta tidak diskriminatif;

8. Hak untuk mendapatkan kompensasi, ganti rugi/penggantian, apabila barang dan/atau jasa yang diterima tidak sesuai dengan perjanjian atau tidak sebagaimana mestinya;

9. Hak-hak yang diatur dalam ketentuan peraturan perundang-undangan lainnya.

Berdasarkan pendapat di atas, maka sebagai konsumen memiliki berbagai hak dalam tindakan pembelian barang serta adanya berbagai perlindungan hukum terhadap konsumen.

Sesuai dengan Pasal 5 Undang-undang Perlindungan Konsumen, Kewajiban Konsumen adalah :

1. Membaca atau mengikuti petunjuk informasi dan prosedur pemakaian atau pemanfaatan barang dan/atau jasa, demi keamanan dan keselamatan.

2. Beritikad baik dalam melakukan transaksi pembelian barang dan/atau jasa.

3. Membayar sesuai dengan nilai tukar yang disepakati.

4. Mengikuti upaya penyelesaian hukum sengketa perlindungan konsumen secara patut.

Adapun pelaku usaha dalam Pasal 6 UUPK adalah sebagai berikut:

1. Hak untuk menerima pembayaran yang sesuai dengan kesepakatan mengenai kondisi dan nilai tukar barang dan/atau jasa yang diperdagangkan;

2. Hak untuk mendapat perlindungan hukum dari tindakan konsumen yang beritikad tidak baik; 
3. Hak untuk melakukan pembelaan diri sepatutnya di dalam penyelesaian hukum sengketa konsumen;

4. Hak untuk rehabilitasi nama baik apabila terbukti secara hukum bahwa kerugian konsumen tidak diakibatkan oleh barang dan/atau jasa yang diperdagangkan;

5. Hak-hak yang diatur dalam ketentuan peraturan perundang-undangan lainnya. ${ }^{21}$

Adapun kewajiban pelaku usaha dalam Pasal 7 UUPK adalah sebagai berikut :

1. Beritikad baik dalam melakukan kegiatan usahanya;

2. Memberikan informasi yang benar, jelas dan jujur mengenai kondisi dan jaminan barang dan/atau jasa serta memberi penjelasan penggunaan, perbaikan dan pemeliharaan;

3. Memperlakukan atau melayani konsumen secara benar dan jujur serta tidak diskriminatif;

4. Menjamin mutu barang dan/atau jasa yang diproduksi dan/atau diperdagangkan berdasarkan ketentuan standar mutu barang dan/atau jasa yang berlaku;

5. Memberi kesempatan kepada konsumen untuk menguji, dan/atau mencoba barang dan/atau jasa tertentu serta memberi jaminan dan/atau garansi atas barang yang dibuat dan/atau yang diperdagangkan;

6. Memberi kompensasi, ganti rugi dan/atau penggantian atas kerugian akibat penggunaan, pemakaian dan pemanfaatan barang dan/atau jasa yang diperdagangkan;

7. Memberi kompensasi, ganti rugi dan/atau penggantian apabila barang dan/atau jasa yang dterima atau dimanfaatkan tidak sesuai dengan perjanjian. ${ }^{22}$

Berdasarkan penganturan di atas, maka tampak bahwa hak dan kewajiban pelaku usaha bertimbal balik dengan hak dan kewajiban konsumen. Ini berarti hak bagi konsumen

\footnotetext{
${ }^{21}$ Ibid, hlm. 60.

${ }^{22}$ Ibid, hlm. 61.
} 
adalah kewajiban yang harus dipenuhi oleh pelaku usaha. Demikian pula dengan kewajiban konsumen merupakan hak yang akan diterima pelaku usaha. Bila dibandingkan dengan ketentuan umum di Kitab Undang-Undang Hukum Perdata, tampak bahwa pengaturan UUPK lebih spesifik. Karena di UUPK pelaku usaha selain harus melakukan kegiatan usaha dengan itikad baik, ia juga harus mampu menciptakan iklim usaha yang kondusif, tanpa persaingan yang curang antar pelaku usaha.

Untuk melindungi para konsumen, maka dalam fikih Islam (fikih muamalah) dikenal berbagai perangkat istilah hukum, seperti ba'i al-gharar (jual beli mengandung tipuan) pemberlakuan hak khiyar (hak untuk melangsungkan atau membatalkan transaksi karena sebuah alasan yang diterima), beberapa hal yang merusak transaksi seperti al-ghalt (tidak adanya persesuaian dalam hal jenis atau sifat barang) dan alghubn (adanya tipuan yang disengaja) dan masih banyak lagi yang lainnya. $^{23}$

Ada beberapa ayat dan hadis yang menjelaskan tentang perlindungan konsumen. Diantaranya sebagai berikut:

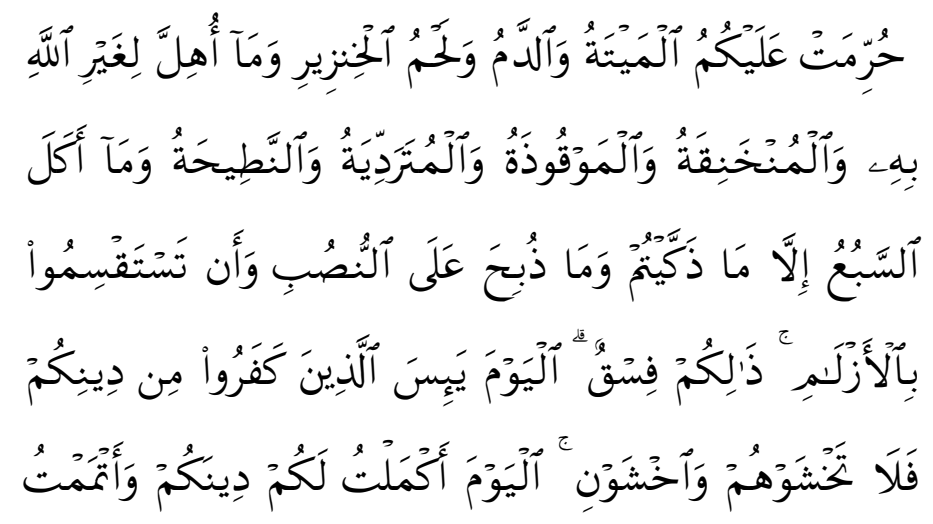

${ }^{23}$ Muhammad dan Alimin, Etika Perlindungan Konsumen dalam Ekonomi Islam, (Yogyakarta: BEFE Yogyakarta, 2004), hlm. 132 


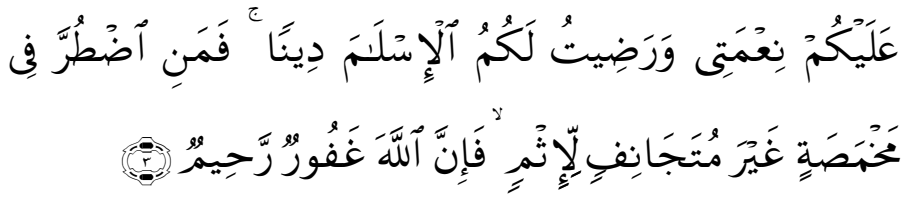

Artinya: "Diharamkan bagimu (memakan) bangkai, darah, daging babi, (daging hewan) yang disembelih, yang jatuh, yang ditanduk, dan yang diterkam binatang buas kecuali yang sempat kamu sembelih dan (diharamkan juga bagimu) yang disembelih untuk berhala. Dan (diharamkan juga) mengundi nasib dengan anak panah; itu adalah suatu kefasikan. (Q.S Al Ma'idah: 3)

Karena itu selain dari yang tersebut dalam ayat ini boleh dimakan, sedangkan bahirah dan wasilah itu tidak tersebut di dalam ayat itu. Memang ada beberapa ulama berpendapat bahwa di samping yang tersebut dalam ayat itu, adalagi yang diharamkan memakannya berdasarkan hadis Rasulullah saw. seperti memakan binatang yang bertaring tajam atau bercakar kuat, tetapi sebagian ulama berpendapat bahwa memakan binatang-binatang tersebut hanya makruh saja hukumnya.

Allah menyuruh manusia memakan yang baik sedang makanan yang diharamkan oleh beberapa kabilah yang ditetapkan menurut kemauan dan peraturan yang mereka buat sendiri halal dimakan, karena Allah tidak mengharamkan makanan itu. Ayat ini menunjukan bahwa konsumen muslim, memiliki kewajiban untuk memakan makanan yang baik dan halal. Oleh sebab itu, produsen wajib untuk memberikan perlindungan dengan mencantumkan label halal pada produk makanan dan minuman.

Selain itu, Allah juga berfirman dalam QS. Al Maaidah: 87. 


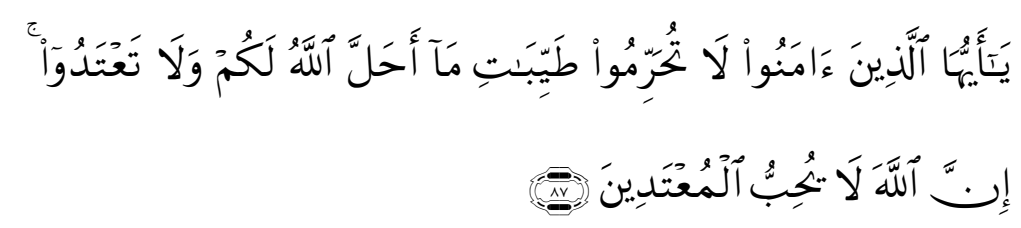

Artinya: "Hai orang-orang yang beriman, janganlah kamu haramkan apa-apa yang baik yang telah Allah halalkan bagi kamu, dan janganlah kamu melampaui batas. Sesungguhnya Allah tidak menyukai orang-orang yang melampaui batas." 24

Pada ayat ayat ini Allah swt. menunjukkan firman-Nya kepada kaum muslimin, yaitu melarang mereka mengharamkan bagi diri mereka segala yang baik yang telah dihalalkan-Nya seperti makanan, minuman, pakaian, pernikahan dan lain-lainnya yang baik dan halal. Ayat ini diturunkan berkenaan dengan beberapa orang sahabat yang keliru dalam memahami dan melaksanakan ajaran-ajaran agama Islam. Mereka mengira, bahwa untuk mendekatkan diri kepada Allah swt. harus melepaskan diri dari segala macam kenikmatan duniawi, karena mereka berpendapat, bahwa kenikmatan itu hanya akan melalaikan mereka beribadat kepada Allah. Padahal Allah swt. telah menciptakan dan menyediakan di muka bumi ini barangbarang yang baik, yang dihalalkan-Nya untuk mereka. Dan di samping itu, Dia telah menjelaskan pula apa-apa yang diharamkan-Nya. ${ }^{25}$

Islam melarang semua transaksi bisnis yang mengandung unsur kecurangan dan ketidakpastian (gharar) dalam segala bentuk terhadap pihak lain; hal itu mungkin dalam bentuk penipuan atau kejahatan, atau memperoleh keuntungan dengan tidak semestinya atau resiko yang menuju ketidakpastian di dalam suatu bisnis atau sejenisnya. ${ }^{26}$ Sebagaimana telah penulis jelaskan diatas, larangan gharar

\footnotetext{
${ }^{24}$ QS. Al-Maidah (5): 87.

${ }^{25}$ QS. Al-Maidah (5): 87.

${ }^{26}$ Afzalur Rahman. Doktrin Ekonomi Islam. hlm. 162.
} 
merupakan salah satu bentuk perlindungan konsumen yang dijamin adalam Islam. Hal ini sesuai firman Allah SWT dalam surat Al-An'am ayat : 152 .

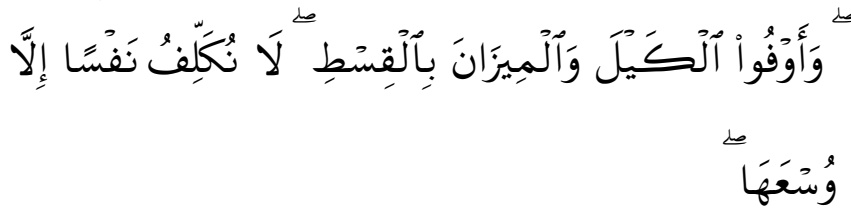

Artinya: "Dan sempurnakanlah takaran dan timbangan dengan adil. Kami tidak memikulkan beban kepada seseorang melainkan sekedar kesanggupannya," (Al-An'am (6):152). ${ }^{27}$

Menurut Oemar Bakry, penggalan ayat tersebut merupakan suruhan untuk mencukupkan timbangan dan takaran yang berarti juga suruhan menepati janji, mutu dan kualitas barang dagangan. Orang tidak diperbolehkan menipu untuk mendapatkan untung. ${ }^{28}$

Ayat tersebut secara jelas telah melarang ketidakpastian (gharar). Kata "Sempurnakanlah timbangan" menunjukan bahwa kita harus melakukan segala sasuatu dengan jelas dan adil. Kita tidak diperbolehkan menipu untuk mendapatkan keuntungan. Allah juga berfirman dalam surat An-Nisa' ayat : 29

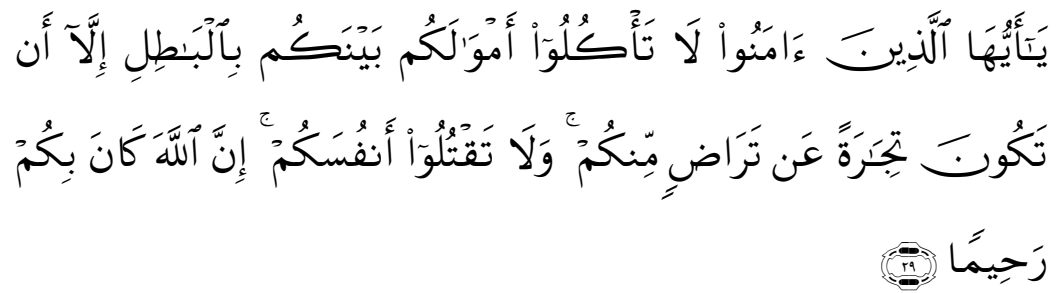

Artinya: "Hai orang-orang yang beriman, janganlah kamu saling memakan harta sesamamu dengan jalan yang batil, kecuali dengan jalan perniagaan yang berlaku dengan suka sama-suka di antara kamu. Dan janganlah kamu

${ }^{27}$ QS. Al-An'am (6):152.

${ }^{28}$ H. Oemar Bakri, Tafsir Rahmat,(Bandung: Tiga Mutiara, 1982), hlm. 277. 
membunuh dirimu, Sesungguhnya Allah adalah Maha Penyayang kepadamu. "(QS. An-Nisa': 29). ${ }^{29}$

Menurut Oemar Bakry ayat ini menjelaskan tentang pemindahan harta seseorang kepada orang lain. Pemindahan itu harus dilakukan dengan cara yang halal dengan kesukaan dan kerelaan timbal balik. Sama-sama mendapatkan manfaat. $^{30}$

Ayat ini adalah ayat yang menjelaskan bahwa ketika ada pemindahan harta, baik melalui transaksi jual-beli, pinjam-meminjam maupun transaksi lainnya, maka harus ada unsur kerelaan antara kedua belah pihak. Keduanya harus sama-sama ridha dan saling mendapatkan manfaat.

Sistem gharar memiliki unsur memakan harta orang lain dengan cara batil. Padahal Allah melarang memakan harta orang lain dengan cara batil sebagaimana tersebut dalam firman-Nya surat Al-Baqarah ayat 188 sebagai berikut:

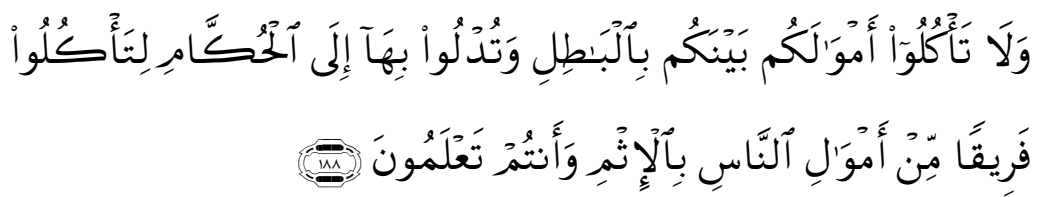

Artinya: "Dan janganlah sebagian kamu memakan harta sebagian yang lain di antara kamu dengan jalan yang batil dan (janganlah) kamu membawa (urusan) harta itu kepada hakim, supaya kamu dapat memakan sebahagian daripada harta benda orang lain itu dengan (jalan berbuat) dosa, padahal kamu mengetahui". (Al-Baqarah/ 2 : 188). ${ }^{31}$

Ayat ini menegaskan bahwa memakan harta sesama dengan jalan bathil adalah sesuatu yang dilarang. Hal ini dikarenakan akan menimbulkan kerugian dan ketidakrelaan. Islam mengajarkan bahwa segala sesuatu itu harus dilakukan karena adanya kerelaan antara pihak-pihak yang bertransaksi di dalamnya.

\footnotetext{
${ }^{29}$ QS. An-Nisa' (4): 29.

${ }^{30}$ H. Oemar Bakri, Tafsir Rahmat., hlm .157

${ }^{31}$ Al-Baqarah (2): 188.
} 
Hadis Rasullulah yang melarang transaksi yang mengandung unsur gharar adalah:

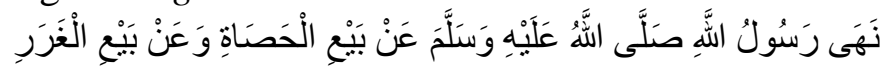

Artinya: "Rasulullah Shallallahu 'alaihi wasallam melarang jual beli al-hashah ( dengan melempar batu) dan jual beli gharar" (HR Ahmad). ${ }^{32}$

Bentuk jual beli yang telah dikemukakan dalam hadis diatas mengandung unsur spekulasi karena tidak jelas harga barang yang diperjualbelikan, tidak jelas ukuran dan kualitas obyek yang dijual. Oleh sebab itu, dalam jual beli harus ada kejelasan obyek yang diperjualbelikan, baik itu kualitas, ukuran, maupun harganya. ${ }^{33}$

Larangan Rasulullah SAW ini tegas melarang adanya jual beli gharar, karena unsur spekulasi dalam jual beli gharar akan merugikan salah satu pihak yang ada dalam trasaksi. Ketidakjelasan dalam jual beli gharar akan menimbulkan kerugian baik dari sisi kualitas, ukuran maupun harga bagi salah satu pihak.

Dalam hal perlindungan konsumen, ketidakjelasan atau gharar in tentu akan merugikan konsumen dan menguntungkan produsen. Konsumen sebagai pengkonsumsi barang akan selalu dirugikan jika ia selalu mengkonsumsi barang yang gharar tersebut. oleh sebab itu, dalam Islam, gharar telah dilarang.

Disamping memberikan perindugan masalah label halal dan larangan gharar, Islam juga emmberikan perlidungan kepada kosnumen melalui hak khiyar. Khiyar artinya memlih, menyisihkan dan menyaring, sedangkan secara terminologis dalam ilmu fiqh, khiyar artinya hak yang dimiliki orang yang melakukan kontrak untuk memilih yang terbaik diantara dua hal, yaitu meneruskan akad atau membatalkan akad. ${ }^{34}$

${ }^{32}$ Enizar, Hadis Ekonomi, (Jakarta: Raja Grafindo Persada, 2014), hlm. 54

${ }^{33}$ Ibid.

${ }^{34}$ Suhrawardi K. Lubis, Hukum Ekonomi, hlm. 146-148. 
Dasar hukum mengenai khiyar diantaranya adalah sebagai berikut:

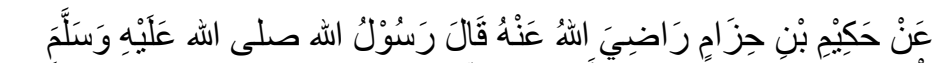

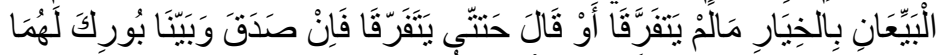

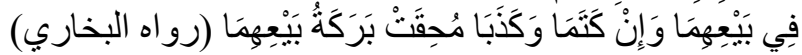

Artinya: "Dari Hakim bin Hizam, dia berkata, Rasullullah Shalllalahu Alaihi wa Sallam bersabda, 'Dua orang yang jual beli mempunyai hak pilih selagi belum saling berpisah', atau beliau bersabda, 'Hingga keduanya saling berpisah, jika keduanya saling jujur dan menjelaskan, maka keduanya diberkahi dalam jual-beli itu, namun jika keduanya saling menyembunyikan dan berdusta, maka barakah jualbeli itu akan dihapuskan"'. (HR.. Bukhori) ${ }^{35}$

Jika kedua belah pihak (penjual dan pembeli) masih berada di tempat pelaksanaan jual-beli, maka masing masing mempunyai hak pilih untuk mengesahkan atau membatalkan jual beli. Jika keduannya saling berpisah, sesuai dengan perpisahan yang dikenal manusia, atau jual-beli disepakati tanpa ketetapan terpilih dari kedua belah pihak, maka akad jual-beli dianggap sah, sehingga salah seorang di antara keduanya tidak boleh membatalkannya secara sepihak, kecuali dengan cara pembatalan perjanjian yang disepakati. ${ }^{36}$

Ada pendapat yang menyatakan bahwa klausa "sebelum keduanya berpisah" dengan makna berpisah kata. Artinya, keduanya belum mengalihkan pembicaraan. Apabila pembicaraan telah diselingi dengan pembicaraan lain, maka masa khiyar telah berakhir. ${ }^{37}$

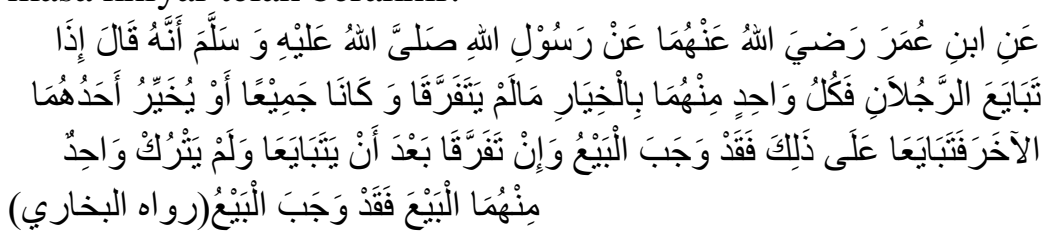

${ }^{35}$ Kathur Suhardi, Edisi Indonesia: Syarah Hadist Pilihan Bukhari Muslim, (Jakarta: Darul Falah, 2002), hlm. 580.

${ }^{36}$ Ibid, hlm. 582.

${ }^{37}$ Enizar, Hadis Ekonomi, (Jakarta: Rajaali Pers, 2013), hlm. 145 
Artinya: "Dari Abdullah bin Umar Radhiyallahu Anhuma, dari Rasulullah SAW, beliau bersabda, "Apabila ada dua orang mengadakan akad jual beli, maka masingmasing boleh khiyar selagi belum berpisah, sedangkan mereka berkumpul; atau salah seorang dari mereka mempersilahkan yang lain untuk khiyar, kalau salah seorang sudah mempersilahkan yang lain untuk khiyar kemudian mereka mengadakan akad sesuai dengan khiyar tersebut, maka jual beli jadi; dan apabila mereka berpisah sementara tidak ada seorangpun yang meninggalkan jual beli (tetap memilih). Khiyar, maka harus jadi." (HR. Bukhori). ${ }^{38}$

Apabila dua orang melakukan transaksi jual beli, dan keduanya telah menyepakati atas harga barang yang akan dijual belikan. Maka masing-masing dari keduanya memiliki hak khiyar (memilih antara membatalkan atau meneruskan jual beli) selama mereka belum berpisah atau masih bersama di tempat jual beli tersebut. Adapun makna يتفرّق yakni berpisah badan antara si penjual dan si pembeli, meskipun Ulama' banyak berpendapat lain tentang memaknai kalimat ini. $^{39}$

Jika salah seorang diantara penjual ataupun pembeli memberikan hak khiyar mereka, dan mereka melakukan transaksi atas dasar itu maka terjadilah jual beli tersebut. (setelah mereka berpisah badan) Dan jika mereka berpisah (Berpisah Badan), setelah melakukan akad jual beli, dan kedua belah pihak (penjual dan pembeli) tidak mengurungkan jual beli, maka jual beli tersebut juga akan tetap terjadi (sah). ${ }^{40}$

Islam juga memberikan hak khiyar berupa khiyar aib kepada para konsumen. Khiyar aib ini merupakan hak khiyar yang diberikan jika ternyata terdapat aib/cacat dalam produk yang dibeli oleh konsumen.

${ }^{38}$ Kathur Suhardi, Edisi Indonesia.,

39 Muhammad bin Ismail al Amir Ash-Shan'ani, Subulu Salam Syarhu Bulughul Maram, (Bandung: Darus Sunnah, 2015), hlm. 807

${ }^{40}$ Ibid. 
Disamping itu, Islam juga memberikan aturan mengenai jual beli yang sah tapi dilarang. Jual beli ini dilaran karena kaan merugikan salah satu pihak dan haya menguntungkan satu pihak lainnya. Jual beli ini antara lain:

1. Membeli barang dengan harga yang lebih mahal dari harga pasar, padahal si pembeli tidak menginginkan barang tersebut, tetapi semata-mata bertujuan supaya orang lain tidak membeli barang tersebut.

2. Membeli barang yang sudah dibeli orang lain atau sudah ditawar orang lain yang masih dalam masa khiyār.

3. Membeli barang dari orang yang datang dari luar kota sebelum sampai di pasar dan mereka belum mengetahui harga yang ada di pasar.

4. Membeli barang untuk ditahan dan dijual kembali pada saat-saat tertentu dengan harga yang lebih mahal, padahal masyarakat umum berhajat terhadap barang tersebut.

5. Jual beli yang sifatnya membohongi, yaitu jual beli yang mengandung unsur kebohongan, baik di pihak penjual maupun pembeli, yang terdapat dalam barang dan ukurannya. $^{41}$

Adanya aturan yang tegas mengenai jual beli ini tidak lain dikarenakan Islam tengah berupaya memberikan perlindungan kepada konsumen. Ini bertujuan untuk memberikan keadilan bagi kedua belah pihak yang bertransaksi dan menciptakan kerelaan atau keridhaan antara kedua belah pihak.

\section{Perlindungan Konsumen Menurut UU No. 8 Tahun 1999 Tentang Perlindungan Konsumen dan Hukum Islam}

Di dalam UUPK telah diatur mengenai hak-hak dan kewajiban-kewajiban konsumen dan pelaku usaha. Berdasarkan kesembilan butir hak yang diberikan kepada konsumen yang di atur dalam UUPK Pasal 4, terlihat bahwa

${ }^{41}$ Ibid, hlm. 62. 
persoalan kenyamanan, keamanan dan keselamatan konsumen merupakan suatu hal yang utama dalam perlindungan konsumen. Barang dan atau jasa yang penggunaannya tidak memberikan kenyamanan, terlebih lagi yang tidak aman atau membahayakan keselamatan konsumen jelas tidak layak untuk diedarkan dalam masyarakat. Selanjutnya, untuk menjamin bahwa suatu barang atau jasa dalam penggunaanya akan nyaman, aman maupun tidak membahayakan konsumen penggunanya, maka konsumen diberikan hak untuk memilih barang atau jasa yang dikehendakinya berdasarkan atas keterbukaan informasi yang benar, jelas dan jujur. Jika terdapat penyimpangan yang merugikan, konsumen berhak untuk didengar, memperoleh advokasi, pembinaan, perlakuan yang adil, kompensasi sampai kepada ganti rugi.

Menyangkut hak pelaku usaha, tampak bahwa UUPK yang mengatur i'tikad baik, lebih ditekankan pada pelaku usaha meliputi semua tahapan dalam melakukan kegiatan usahanya, sehingga dapat diartikan bahwa kewajiban pelaku usaha beritikad baik dimulai sejak barang dirancang atau diproduksi sampai pada tahap purnapenjualan. Sebaliknya konsumen hanya dijwajibkan beritikad baik dalam melakukan transaksi pembelian barang dan/atau jasa. Hal ini disebabkan karena kemungkinan terjadinya kerugian bagi konsumen dimulai sejak barang dirancang oleh pelaku usaha, sedangkan bagi konsumen kemungkinan untuk dapat merugikan pelaku usaha atau produsen dimulai pada saat transaksi.

Jika ditinjau dari hukum Islam, pemakaian istilah hak itu sendiri sebenarnya dalam bahasa Arab menempati banyak arti seperti ketetapan, yang pasti, penjelasan, kebenaran, jatah atau bagian, hakikat dan kewajiban. Istilah hak oleh para ahli hukum Islam sebagaimana yang dikemukakan ole Wahbah Zuhaily yaitu "Suatu sifat kekhususa dimana dengannya 
syara' menetapkan suat kekuasaan bagi pemiliknya atau kewajiban ata objeknya". ${ }^{2}$

Dalam hukum ekonomi Islam kemungkinan pelanggaran akan hak konsumen bisa terjadi ketika sebelum terjadi transaksi jual beli berlangsung, yakni pada saat iklan atau promosi. Bisa pula ketika transaksi itu sendiri berlangsung dan ketika purnatransaksi. Oleh karenanya pada tahapan-tahapan inilah seharusnya perlindungan hukum dapat diberikan. dalam kajian fiqih Islam kebenaran dan keakuratan informasi ketika seorang pelaku usaha mempromosikan barang dagangannya menempati kajian yang signifikan. Islam tidak mengenal istilah bahwa konsumen yang harus berhati-hati atau sebaliknya pelaku usahalah yang harus berhati-hati. Di dalam Islam yang berlaku adalah prinsip keseimbangan. Disni antara keduabelah pihak konsumen maupun pelaku usaha harus sama-sama berhatihati.

Diantara sekian banyak hak konsumen yang mendapat pembahasan dalam kajian fiqih,maka penulis dapat membutirkannya sebagai berikut: (1) Hak untuk mendapatkan informasi dan pelayanan yang benar, jujur, adil, mendidik dan terhindar dari pemalsuan; (2) Tersedianya hak pilih dan nilai tukar yang wajar; (3) Hak untuk mendapatkan keamanan produk dan lingkungan sehat; (4) Hak untuk mendapatkan advokasi dan penyelesaian sengketa; (5) Hak untuk mendapatkan perlindungan dari penyalahgunaan keadaan; (6) Hak untuk mendapatkan ganti rugi akibat negatif dari suatu produk.

Berdasarkan hak-hak di atas, dalam kajian fiqih Islam kebenaran dan keakuratan informasi ketika seorang pelaku usaha mempromosikan barang dagangannya menempati

${ }^{42}$ M. Yusri, Kajian Undang-Undang Perlindungan Konsumen Dalam Perspektif Hukum Islam dalam Jurnal Ulumuddin, Malang: Universitas Muhammadiyah Malang, Volume V, Tahun III, JuliDesember 2009, hlm. 367. 
kajian yang signifikan. Islam tidak mengenal istilah bahwa konsumen yang harus berhati-hati atau sebaliknya pelaku usahalah yang harus berhati-hati. Di dalam Islam yang berlaku adalah prinsip keseimbangan. Disni antara keduabelah pihak konsumen maupun pelaku usaha harus sama-sama berhati-hati. UUPK Pasal 18, mengatur hal menyangkut dengan adanya pencantuman klausula baku atau pernyataan selanjutnya setelah perjanjian awal oleh pelaku usaha tentang suatu produk yang hal ini hanya dilakukan secara sepihak.

Disamping itu, di dalam Islam Informasi produk yang diberikan kepada konsumen tidak hanya berhubungan dengan kuantitas dan kualitas suatu barang (UUPK Pasal 4 huruf C), akan tetapi juga berkaitan dengan efek samping atau bahaya pemakaian, kepercayaan terhadap agama tertentu, seperti informasi halal atau haramnya suatu produk. Resiko pemakaian barang dikenakan pada pelaku usaha sebagai penyebab kerugian karena melanggar prinsip hatihati atau sewenang-wenang dalam penggunaan hak.

Dalam persoalan pemenuhan hak konsumen terhadap harga yang tidak normal dipasar, sebenarnya fiqih Islam telah menawarkan banyak solusi, yaitu dengan pelanggaran praktik ribawi, pelanggaran monopoli dan persaingan tidak sehat. ${ }^{43}$ Demikian hal yang menyangkut hak-hak konsumen dalam Islam. Sebagai bentuk keseimbangan, konsumen pun harus dibebani dengan kewajiban yang walaupun tidak dijelaskan secara spesifik, akan tetapi penulis dapat menjelaskannya sebagai berikut: (1) Beritikad baik dalam melakukan transaksi barang dan/atau jasa; (2) Mencari informasi dalam berbagai aspek dari suatu barang dan/atau jasa yang akan dibeli atau digunakan; (3) Membayar sesuai dengan harga atau nilai yang telah disepakati dan dilandasi rasa saling rela, yang terealisasi

\footnotetext{
${ }^{43}$ Muhammad dan Alimin, Etika Perlindungan., hlm. 213.
} 
dengan adanya ijab dan qabul; (4) Mengikuti penyelesaian hukum terhadap sengketa yang terkait dengan perlindungan konsumen.

Untuk dapat mewujudkan perlindunga terhadap konsumen, hal ini sangat tergantung pula pada kewajiban dan tanggungjawab yang harus dipenuhi oleh pelaku usaha terhadap konsumen. Dalam ketentuan UUPK Pasal 27 huruf (e) disebutkan bahwa, Pelaku usaha yang memproduksi barang dibebaskan dari tanggungjawab atas kerugian yang diderita konsumen apabila; lewat jangka waktu penuntutan 4 tahun sejak barang dibeli atau lewatnya jangka waktu yang diperjanjikan. ${ }^{44}$ Dalam Islam, segala perbuatan yang dapat merugikan satu pihak tidak dibatasi pertanggungjawabannya dengan adanya jangka waktu. Selama kerugian yang ditimbulkan memang benar disebabkan oleh pihak tersebut, maka pertanggungjawaban tetap ada demi tercapainya asas keseimbangan yang berlaku.

Adapun prinsip-prinsip hukum Islam dalam tanggungjawab pelaku usaha diantaranya mencakup prinsip tauhîd, keadilan (al'adl), amar ma'rûf nahiy munkar, prinsip kemerdekaan atau kebebasan (al-Hurriyah), Prinsip alTa'awwun (tolong-menolong) dan toleransi.

Tujuan menghindari eksploitasi terhadap manusia dalam Islam, secara garis besar tidak jauh berbeda dengan tujuan diundangkannya UUPK di Indonesia, yaitu sebagai bentuk perlindungan terhadap konsumen. Hanya saja pengertian konsumen yang dimaksud dalam UUPK yang membedakan cakupan diatara kedua hukum ini.

Keadilan dalam hukum Islam berarti pula keseimbangan antara kewajiban yang harus dipenuhi oleh manusia dengan kemampuan manusia untuk menunaikan kewajiban itu. Jikak eadilan dilanggar maka akan terjadi

44 Undang-undang No. 8 Tahun 1999 tentang Perlindungan Konsumen Pasal 27 huruf (e) 
ketidak-seimbangan dalam pergaulan hidup, sebab satu pihak akan dirugikan atau disengsarakan sementara yang lain memperoleh keuntungan. Jika sistem sosial rusak karena keadilan dilanggar maka pastilah seluruh masyarakat akan mengalami kerusakan yang dampaknya akan menimpa banyak orang.

Dari beberapa kewajiban pelaku usaha yang diatur dalam pasal 27 UUPK, dapat disimpulkan bahwasanya pengaruh negatif yang akan timbul dari kewajiban-kewajiban tersebut jika terjadi pelanggaran, hanya mengikutkan dua belah pihak diantara konsumen dan pelaku usaha. Di dalam etika Islam di bidang bisnis sebuah kewajiban yang dipenuhi atau dilanggar, akibatnya harus dengan berbagai pertimbangan yang tidak hanya berpengaruh kepada kedua belah pihak diantara konsumen dan pelaku usaha namun juga keterlibatan sosial masyarakat dan agama. Tanggung jawab sosial dari bisnis ialah pelaksanaan etika bisnis yang mencakup proses produksi, distribusi barang dan jasa sampai penjagaan kelestarian lingkungan hidup dari ancaman polusi dan sebagainya. Pelaku usaha atau perusahaan tidak hanya bertanggung jawab memenuhi kewajiban terhadap pemenuhan kebutuhan konsumen sesaat, akan tetapi juga perlu mempertimbangkan jangka panjang kelangsunngan hidup manusia dan ekologi kemaslahatan umum.

Antara Undang-Undang No. 8 Tahun 1999 tentang perlindungan Konsumen dan Hukum Islam, terdapat persamaan dan perbedaan. Persamaannya diantaranya adalah dalam hal kewajiban pelaku usaha dalam beriktikad baik dimulai sejak barang dirancang sampai pada tahap purna penjualan. Sementara itu, perbedaannya adalah sebagai berikut: 


\begin{tabular}{|l|l|}
\hline $\begin{array}{l}\text { Menurut yang diatur dalam } \\
\text { UUPK }\end{array}$ & $\begin{array}{l}\text { Menurut yang diatur dalam } \\
\text { Islam }\end{array}$ \\
\hline $\begin{array}{l}\text { Hak konsumen maupun } \\
\text { pelaku usaha bersifat mutlak } \\
\text { ditentukan dalam Undang- } \\
\text { Undang/UUPK }\end{array}$ & $\begin{array}{l}\text { Hak konsumen maupun } \\
\text { pelaku usaha tidak bersifat } \\
\text { mutlak dan ditentukan oleh } \\
\text { syara' }\end{array}$ \\
\hline $\begin{array}{l}\text { Hak informasi yang diterima } \\
\text { konsumen menyangkut } \\
\text { dengan kualitas dan } \\
\text { kuantitas produk }\end{array}$ & $\begin{array}{l}\text { Hak informasi yang diterima } \\
\text { konsumen selain menyangkut } \\
\text { kualitas dan kuantitas juga } \\
\text { termasuk informasi kehalalan } \\
\text { suatu produk }\end{array}$ \\
\hline $\begin{array}{l}\text { Hak konsumen dalam } \\
\text { kebebasan memilih barang } \\
\text { diukur dengan nilai tukar } \\
\text { yang pantas terhadap suatu } \\
\text { produk }\end{array}$ & $\begin{array}{l}\text { Hak konsumen dalam } \\
\text { kebebasan memilih barang, } \\
\text { selain diukur dengan nilai } \\
\text { tukar juga } \\
\text { mempertimbangkan hak } \\
\text { orang lain yang terlebih } \\
\text { dahulu melakukan penawaran } \\
\text { terhadap suatu produk }\end{array}$ \\
\hline
\end{tabular}

\section{E. Kesimpulan}

Berdasarkan uraian di atas, maka dapat disimpulkan bahwa keberadaan Undang-Undang Nomor 8 Tahun 1999 tentang Perlindungan Konsumen dan Hukum Islam samasama berupaya untuk memberikan perlindungan terhadap konsumen. Ada beberapa persamaan dan perbedaan antara Undang-Undang Nomor 8 Tahun 1999 tentang Perlindungan Konsumen dan Hukum Islam, diantaranya dalam UndangUndang Nomor 8 Tahun 1999 hak konsumen maupun pelaku usaha bersifat mutlak ditentukan dalam Undang-Undang, sementara dalam hukum Islam Hak konsumen maupun pelaku usaha tidak bersifat mutlak dan ditentukan oleh syara'. Selain itu, hak informasi yang diterima konsumen dalam hukum Islam lebih luas, karena selain menyangkut kualitas dan kuantitas juga termasuk informasi kehalalan suatu produk. Begitu halnya dengan hak konsumen dalam kebebasan memilih barang, selain diukur dengan nilai tukar 
juga mempertimbangkan hak orang lain yang terlebih dahulu melakukan. Hal ini menunjukkan bahwa hukum Islam lebih luas dan fleksibel dalam memberikan perlindungan terhadap konsumen.

\section{Daftar Pustaka}

Achmad Aghar Basyir, Prinsip-prinsip Ekonomi Islam Dalam Bebagai Aspek Ekonomi Islam, Yogyakarta: P3Ei-FE UII bekerjasama dengan Penerbit Tiara Wacana, 1992.

Ahmadi dan Yodo, Hukum Perlindungan Konsumen, (Jakarta : Rajawali Pers, 2004.

Az. Nasution, Hukum Perlindungan Konsumen-Suatu Pengantar, Jakarta: Daya Widya, 1999.

Badan Pembinaan Hukum Nasional (BPHN) Departemen Kehakiman, Simposium, Aspek-Aspek Hukum Masalah Perlindungan Konsumen, Jakarta: Binacipta, 1986.

Celina Tri Siwi Kristiyanti, Hukum Perlindungan Konsumen, Jakarta: Sinar Grafika, 2009.

Enizar, Hadis Ekonomi, Jakarta: Rajaali Pers, 2013.

Janus Sidabalok, Hukum perlindungan Konsumen, Bandung: PT. Citra Aditya Bakti, 2006.

Kathur Suhardi, Edisi Indonesia: Syarah Hadist Pilihan Bukhari Muslim, Jakarta: Darul Falah, 2002.

M. Yusri, Kajian Undang-Undang Perlindungan Konsumen Dalam Perspektif Hukum Islam dalam Jurnal Ulumuddin, Malang: Universitas Muhammadiyah Malang, Volume V, Tahun III, Juli-Desember 2009.. 
Moh. Mahfud MD, Pewadahan Etika Keilmuan di Dalam UU Hak Cipta, Jurnal Hukum Ius Quiaiustum UII, Yogyakarta, 1999.

Siahaan, Hukum Perlindungan Konsumen dan Tanggung Jawab Produk, Jakarta: Panta Rei, 2005.

Muhammad bin Ismail al Amir Ash-Shan'ani, Subulu Salam Syarhu Bulughul Maram, Bandung: Darus Sunnah, 2015.

Muhammad dan Alimin, Etika Perlindungan Konsumen dalam Ekonomi Islam, Yogyakarta: BEFE Yogyakarta, 2004.

Neni Sri Imaniyati, Hukum Ekonomi dan Ekonomi Islam Dalam Perkembangan, Bandung: Mandar Maju, 2002.

Oemar Bakri, Tafsir Rahmat, Bandung: Tiga Mutiara, 1982.

Satjipto Rahardjo, Pembangunan Hukum Yang Diarahkan Kepada Tujuan Nasional, Yogyakarta: Tiara Wacana, 2009.

Shidarta, Hukum Perjanjian Konsumen Indonesia, Jakarta: Grasindo, 2000.

Sri Redjeki Hartono, Aspek-aspek Hukum Perlindungan Konsumen Dalam Menghadapi Era Perdagangan Bebas, Bandung: UNISBA, 1998.

Undang-undang No. 8 Tahun 1999 tentang Perlindungan Konsumen. 
172 Nurul Tika Pratiwi dan Aprina Chintya: Studi Komperatif....

Fikri, Vol. 2, No. 1, Juni 2017 